\title{
Nutritional and antinutritional values of leaves and stems of Ocimum tenuiflorum $\mathbf{L}$.
}

\author{
${ }^{1}$ Mousavi, L., ${ }^{1,}{ }^{*}$ Rabeta, M.S. and ${ }^{2}$ Murugaiyah, V. \\ ${ }^{1}$ Food Technology Division, School of Industrial Technology, Universiti Sains Malaysia, 11800 Minden, \\ Penang, Malaysia \\ ${ }^{2}$ Discipline of Pharmacology, School of Pharmaceutical Sciences, Universiti Sains Malaysia, 11800 \\ Minden, Penang, Malaysia
}

\begin{abstract}
Article history:
Received: 15 May 2019

Received in revised form: 10

June 2019

Accepted: 12 June 2019

Available Online: 25 June

2019
\end{abstract}

\section{Keywords:}

Ocimum tenuiflorum L.,

Nutritional and

Antinutritional Compounds, HPLC,

GC-MS

DOI:

https://doi.org/10.26656/fr.2017.3(6).160

\begin{abstract}
Ocimum tenuiflorum L., commonly known as ruku in Malaysia, is usually cultivated as a garden ornamental plant because of its small purplish and some yellowish flower. Additionally, the young leaves of $O$. tenuiflorum L. are used to make Nasi Ulam. In this study, we investigated the nutritional values of $O$. tenuiflorum leaves and stems to find a rich source of essential nutrients needed in daily diet. High pressure liquid chromatography (HPLC) and gas chromatography/mass spectrophotometer (GC/MS) methods were used to measure the amino acid and fatty acid content of leaves and stems of O. tenuiflorum L. The result of antinutritional compositions of the leaves and stems displayed as a safe range of compounds that were effective to increase absorption of nutritional compound by body cells. The result of fatty acid profile showed that the butanoic acid as the highest amount of fatty acid content in stems and leave compared to other fatty acid compositions. The result of amino acids profile indicated that $\alpha$ aminobutyric acid and cysteine (non-essential amino acid) showed the highest and the lowest amount of amino acid content in stem and leaves consequently. Vitamin $\mathrm{E}$ and $\mathrm{C}$ showed the high and lowest amount of vitamins content in the leave and stem, respectively. In conclusion, the result of antinutritional and nutritional contents of $O$. tenuiflorum $\mathrm{L}$. leaves and stems clearly indicated that the antinutritional compounds were in the safe range. The amount and nutritional content of the leaves and stem proved that this plant a good source to improve our body health system.
\end{abstract}

\section{Introduction}

There has been a correlation conducted by epidemiological studies regarding certain diets, specific foods, and disease expression since the last three decades (Bidlack et al., 2000). Currently, the discovery of cheaper sources of protein and other nutrients is highly considered by researchers. This could be found from most plant materials, which are mostly under-utilized (Eknayake et al., 1999). Beside of that, each particular plant species or group having its own unique medicinal actions are consistent with this concept. There are many reports due to different unique compound from a different family of plants as a nutritional compound which is useful for the treatment of special disease (Bidlack et al., 2000). However, between many plant varieties and family, the plant in Lamiaceae family showed valuable properties in medicinal preparations, flavoring, confectionery, cosmetics, and perfumery as an aromatic herbs plants (Magness, 2006). Due to the abundant content of essential oils within these plants family, they can perform antibacterial, antimicrobial, and suppressive activities against tumour formation (Farhat et al., 2001).

Ocimum tenuiflorum L., commonly known as ruku in Malaysia, is usually cultivated as a garden ornamental plant because of its small purplish and some yellowish flower. Additionally, the young leaves of $O$. tenuiflorum L. are used to make Nasi Ulam. Due to its high medical potential, $O$. tenuiflorum, becomes one of the few wonder herbs (Kothari et al., 2004). This can be seen from the content of essential oil within the leaves, where various compounds of medical value are available (Rai et al., 2004). Due to the numerous curatives uses of this plant, it is thought to be highly sacred in India (Kothari et al., 2004). Many studies regarding the effects of various drying methods performed on the antioxidant capacity of $O$. tenuiflorum have displayed several promising results (Rabeta and Lai, 2013). In addition, the 
reports have been recorded regarding the anti-microbial evaluation (Mousavi et al., 2014), antidiabetic properties (Mousavi et al., 2016) and promote wound healing (Rohini et al., 2019) of O. tenuiflorum.

However, no report has been made regarding the nutritional and antinutritional values of $O$. tenuiflorum $\mathrm{L}$. leaves and stems. Therefore, the potentials of the chemical composition (proximate analysis, amino acid profile, fatty acid, vitamins, and antinutritional composition) of frozen and dried leaves and stems of $O$. tenuiflorum L. were investigated in this research. Finally, the quantity of various nutrients present and the nutritional value of the leaves and stems will be determined separately by the parameters.

\section{Materials and methods}

\subsection{Plant material and preparation of sample}

The fresh sample $O$. tenuiflorum leaves and stem was collected from Perak (Malaysia). Then, the sample was identified and kept at the Herbarium of the School of Biological Sciences, Universiti Sains Malaysia (USM Herbarium number 11400). Flowers and leaves were separated from the stem and cleaned with tap water. Damaged leaves were removed and the remains were rinsed with distilled water. Then, the samples were freeze-dried for three days following Ratti (2001) protocol. After completely dried, the samples were ground into powder form using a blender. The powder was packaged in vacuum pack and kept at $4^{\circ} \mathrm{C}$ (Toshiba, GR-M48MP, Minato-Ku, Japan) for further analysis (Eknayake et al., 1999).

\subsection{Proximate analysis}

The test on the contents of moisture, ash, and fat were conducted following the methods of Association of the Official Analytical Chemists (AOAC, 2000). All measurements were performed in triplicate. The carbohydrate content was calculated with the equation below:

$\%$ Carbohydrate $=100 \%-(\%$ Crude protein $+\%$ Crude fat $+\%$ Crude fiber $+\%$ Ash)

\subsection{Fatty acid analysis}

Upon hydrolyzation, fatty acid analysis within the leaves and stems of $O$. tenuiflorum $\mathrm{L}$. was performed by gas chromatography (GC) separately. Flame ionization detector was used for the injection process into a Gas Chromatography (GC-MS, 17-A-Shimadzu Scientific Inc., USA). The column used was the $30 \mathrm{~m} \times 0.25 \mathrm{~mm}$ fused silica capillary, with $70 \%$ cyanopropylpolysilphenylene-siloxane of $0.25 \mu \mathrm{m}$ film thickness coated on it. Hydrogen was used as a the carrier gas at a constant linear velocity, $28 \mathrm{~cm} / \mathrm{s}$. The temperature used for injection was $250^{\circ} \mathrm{C}$, while the temperature for the detector was $280^{\circ} \mathrm{C}$. The programming of the oven was as follows: $80^{\circ} \mathrm{C}$ set for 2 minutes, $5^{\circ} \mathrm{C} / \mathrm{min}$ to $200^{\circ} \mathrm{C}$ set for $10 \mathrm{mins}$, and $10{ }^{\circ} \mathrm{C} /$ min to $230^{\circ} \mathrm{C}$ set for another 10 mins.

\subsection{Amino acids analysis}

Amino acids analysis was performed according to the method of Boogers et al. (2008). Samples were subjected to hydrolysis process using $6 \mathrm{~N} \mathrm{HCl}$ at $110^{\circ} \mathrm{C}$ in screw-capped tubes. Reverse-phase HPLC with the AccQ-Tag $3.9 \times 150 \mathrm{~mm}$ column at a temperature of $35^{\circ} \mathrm{C}$, a fluorescence detector Mod.474 $\left(\lambda_{\text {ecc }}=285 \mathrm{~nm}\right.$; $\lambda_{\mathrm{em}}=345 \mathrm{~nm}$ ), an auto sampler programmed with injector, and a water system with Alliance 2690 Separation Module pump and "AccQ-Fluor Reagent Kit Watres" (borate buffer, AQC, $\mathrm{CH}_{3} \mathrm{CN}$; Cat. No. 052880) was used in order to conduct the derivatization procedure. Eluents comprised of the gradient of phosphate buffer $\mathrm{H}_{2} \mathrm{O}$ (C) (flow-rate $1.0 \mathrm{~mL} / \mathrm{min}$ ), $\mathrm{CH}_{3} \mathrm{CN}$ (B), and $\mathrm{pH} 5.80$ (A) (Strydom and Cohen, 1994).

\subsection{Water soluble and fat-soluble vitamin analysis}

All chemicals of analytical reagent grade were used for this analysis. Vitamins standards (purity $>99.0 \%$ ), such as $\alpha$-tocopherol (E), folic acid (B12), niacin (B3), and ascorbic acid (C), butylatedhydroxytoluene (BHT), triethylamine (TEA), trans- $\beta$-Apo-8́-carotenal, hippuric acid, and internal standards were purchased from Sigma Aldrich (Madrid, Spain). Water soluble vitamin standard solutions and hippuric acid solution $(1 \mathrm{mg} / \mathrm{mL})$ was prepared in $10 \mathrm{mM}$ of ammonium acetate $(\mathrm{pH} 4.5)$ and stored in the dark at $4^{\circ} \mathrm{C}$. The folic acid $(0.01 \mathrm{mg} / \mathrm{mL})$, pyridoxine $(1 \mathrm{mg} / \mathrm{mL})$, niacin, and ascorbic acid ( $5 \mathrm{mg} /$ $\mathrm{mL}$ ) were prepared in different volume. Following that, trans- $\beta$-Apo- 8 -carotenal, $\beta$-carotene, and $\alpha$-tocopherol were dissolved in methanol $(1 \mathrm{mg} / \mathrm{mL})$ and kept at $-20^{\circ} \mathrm{C}$ in dark condition. Further analysis was performed by HPLC-MS/MS (Thermo Scientific, San Jose, CA) and the diode array detector (DAD) was used as an auto sampler, followed by a TSQ Quantum triple quadruple analyzer (Thermo Scientific).

In addition, an electro spray (ESI) interface was used to pair the chromatograph to MS analyzer. The column number ACE-100 C18 $(100 \times 2.1 \mathrm{~mm}$ i.d., $3 \mu \mathrm{m}$ particle size) was used for the analysis (Advanced Chromatographic Technologies, Aberedeen, UK) (Tayade et al., 2013). Meanwhile, the determination of FSV was conducted in an Agilent 1100 HPLC chromatograph (Agilent, Palo Alto, CA), the analytical column of $\mathrm{YMC} \mathrm{C}_{30}$, a diode array detector (DAD,) and 
auto sampler being included according to Santos et al. (2012).

\subsection{Phytochemical determination}

\subsubsection{Total saponin}

The spectrophotometric assay was referred to the method described by Baccou et al. (1977). Ground leave and stem of $0.5 \mathrm{~g}$ each was weighed and added with 10 $\mathrm{mL}$ of $80 \%$ aqueoue methanol. The mixture was stirred and then centrifuged at $3000 \times \mathrm{g}$ for $10 \mathrm{mins}$. The supernatant was collected and transferred into $25 \mathrm{~mL}$ measuring flasks. The residue was added with $5 \mathrm{~mL}$ of $80 \%$ aqueous methanol, centrifuged and the supernatant was collected into the measuring flasks. This step was repeated three times. The supernatant was added with $80 \%$ aqueous methanol until $25 \mathrm{~mL}$. In order to determine the saponin, aliquot samples from the flasks were involved. The expression of the results was calculated by the diosgenin equivalents from a standard curve.

\subsubsection{Total phytic acid}

Analysis on the total phytic acid content was conducted according to the method described by Vaintraub and Lapteva (1988) with some modifications. In brief, $0.5 \mathrm{~g}$ of sample was weighed into a beaker and added with $10 \mathrm{~mL}$ of $3.5 \% \mathrm{HCl}$. The mixture was stirred at $1700 \mathrm{rpm}$ for $1 \mathrm{hr}$ followed by centrifugation at 3500 rpm for 10 mins. To remove the anthocyanin pigments which might disrupt the assay, centrifugation of the obtained supernatant was conducted once more, using activated carbon. The supernatant was decanted and filtered using Whatman No. 1 filter paper. Spectrophotometric assay was performed on the centrifuged mixture an aliquot $(1 \mathrm{~mL})$ of filtrate with 2 $\mathrm{mL}$ of distilled water and $1 \mathrm{~mL}$ of Wage reagent $(0.03 \%$ of $\mathrm{FeCl} 3.6 \mathrm{H} 2 \mathrm{O}$ with $0.3 \%$ sulphosalicylic acid) and measured its absorbance at $500 \mathrm{~nm}$. Phytic acid mg/100g was calculated according to the calibration curve of standard.

\subsubsection{Flavanoids}

The extraction process was performed by macerating $10 \mathrm{~g}$ of sample with $100 \mathrm{~mL}$ of $80 \%$ aqueous methanol at room temperature for 5 to $10 \mathrm{mins}$. The contents were filtered with a Whatman filter paper No. $42(125 \mathrm{~mm})$. The filtrate was transferred into a crucible and dried until a constant weight was achieved. Analysis and calculation of the flavonoid percentage was conducted according to method described by (Boham and Kocipai-Abyazan, 1974).

$$
\% \text { Flavonoids }=\frac{\mathrm{W}_{2}-\mathrm{W}_{1}}{\text { Weight of Sample }} \times 100
$$

$\mathrm{W}_{1}=$ Weight of empty crucible, $\mathrm{W}_{2}=$ Weight of crucible
+ residue

\subsubsection{Alkaloids}

In this process, $5 \mathrm{~g}$ of the sample was weighed into a $250 \mathrm{~mL}$ beaker, followed by the addition of $200 \mathrm{~mL}$ of $10 \%$ acetic acid in ethanol $\left(\mathrm{C}_{2} \mathrm{H}_{5} \mathrm{OH}\right)$. After that, the mixture was kept at room temperature under dark condition. Then, the mixture was filtered with Whatman filter paper No. 42 and subsequently concentrated using a water bath until quarter of the original volume was obtained. Drops of concentrated $\mathrm{NH}_{4} \mathrm{OH}$ was then added. Alkaloids percentage of samples was evaluated due to the method described by (Doss, 2009).

$$
\% \text { Alkaloids }=\frac{\mathrm{W}_{2}-\mathrm{W}_{1}}{\text { Weight of Sample }} \times 100
$$

$\mathrm{W}_{1}=$ Weight of empty filter paper, $\mathrm{W}_{2}=$ Weight of filter paper + Alkaloid

\subsubsection{Total tannin}

The total tannin content was determined with the Follin Denis titrating method was as described by Kokke (1977). Approximately $100 \mathrm{~mL}$ of petroleum ether was added into $20 \mathrm{~g}$ of the crushed sample within a conical flask, before it was covered for $24 \mathrm{hrs}$. Then, filtration on the sample was conducted followed by standing of 15 mins, with the purpose of enabling the evaporation of petroleum ether. A total of $4 \mathrm{hrs}$ were taken in order to re -extract the sample, where it was soaked in $100 \mathrm{~mL}$ of $10 \%$ of acetic acid in ethanol. After filtration of the sample, $25 \mathrm{~mL}$ of $\mathrm{NH}_{4} \mathrm{OH}$ was added to the filtrate for the precipitation process performed on the alkaloids. In order to remove some of the remaining $\mathrm{NH}_{4} \mathrm{OH}$ within the solution, heating process was performed on the alkaloids. A total of $5 \mathrm{~mL}$ of precipate was taken and added with $20 \mathrm{~mL}$ of ethanol. Using phenolphthalein as an indicator, the liquid was titrated with $0.1 \mathrm{M}$ of $\mathrm{NaOH}$ until the end point.Calculation was made on the tannin content using $\%\left(\mathrm{C}_{1} \mathrm{~V}_{\mathrm{I}}=\mathrm{C}_{2} \mathrm{~V}_{2}\right)$ molarities.

\subsubsection{Total phenols}

The total phenols was determined via spectrophotometric method following Edeoga et al. (2005). Using $50 \mathrm{~mL}$ of diethylether $\left(\mathrm{CH}_{3} \mathrm{CH}_{2}\right)_{2}$, the fatfree sample was boiled followed by the transfer of 0.5 $\mathrm{mL}$ of the boiled extract into $50 \mathrm{~mL}$ of flask and added with $10 \mathrm{~mL}$ of distilled water. Then, $5 \mathrm{~mL}$ of concentrated amylalcohol and $2 \mathrm{~mL}$ of ammonium hydroxide solution were added $\left(\mathrm{CH}_{3}\left(\mathrm{CH}_{2}\right)_{3} \mathrm{CH}_{2} \mathrm{OH}\right)$. The absorbance was measured at $505 \mathrm{~nm}$.

Conc. of Sample $(\mathrm{mg} / \mathrm{L})=\frac{\text { Absorbance of sample } \times \text { Conc. of sample }}{\text { Absorbance of Standard }}$ 


\subsection{Statistical analysis}

For each measurement, triplicates were performed. Results were expressed as mean \pm SEM and SPSS (version 21.0) was utilized to perform $\mathrm{t}$-test at $\mathrm{p}<0.05$.

\section{Results and discussion}

\subsection{Proximate composition of O. tenuiflorum L. leaves and stems}

Table 1 shows that the result of the proximate analysis (\%) of leaves and stems of $O$. tenuiflorum $\mathrm{L}$. Based on the result, there were significant differences between leaves and stems, which could be seen from the fat and crude protein content in the leaves. To illustrate this, the amount of fat and crude protein content in leaves was higher, in comparison to the amount within the stems. However, based on the results, the amount of the protein content within the leaves and stems was slightly lesser, compared to the protein content of $O$. grastismium leaves. This result was reported by (Idris et al., 2011). In contrast, there was a higher fat content within $O$. tenuiflorum Leaves, compared to the amount of fat content within $O$. grastismium plant. This was reported by (Idris et al., 2011). Nevertheless, due to the protein's function as enzymes, hormones, and antibodies, it holds a high importance (Rampal et al., 2010). Furthermore, besides having its has an essential role in the formulation of the outer layer of skin, hair, teeth, and bones, it aids in the maintenance of the structure of blood vessels and other tissues (Rampal et al., 2010). Based on the result of our finding, it had shown that the stem of $O$. tenuiflorum L. lacked of lipids. This can be observed from the contents of food within leafy vegetables with low lipid. This provides health benefits which help avoid obesity (Lintas and Cappelloni, 1992).

Table 1. Proximate composition of Ocimum tenuiflorum L. leaves and stems (\% d.b.)

\begin{tabular}{lcc}
\hline \multirow{2}{*}{ Parameters } & \multicolumn{2}{c}{ Composition } \\
\cline { 2 - 3 } & Leaves & Stems \\
\hline Crude Protein & $12.69 \pm 0.61^{*}$ & $5.21 \pm 0.11$ \\
Crude Fibre & $0.56 \pm 0.05$ & $0.87 \pm 0.03^{*}$ \\
Ash & $0.3 \pm 0.05^{*}$ & $0.17 \pm 0.06$ \\
Moisture content & $14.71 \pm 0.61^{*}$ & $9.41 \pm 0.71$ \\
Fat & $0.04 \pm 0.0^{*}$ & $0.01 \pm 0.00$ \\
Carbohydrate & $71.7 \pm 0.05$ & $84.33 \pm 0.04^{*}$ \\
\hline
\end{tabular}

Values are expressed as mean \pm SEM. *Significantly different $\mathrm{p}<0.05$.

The largest amount of the crude fiber content of the stem $(0.87 \pm 0.03)$ was present significantly, in comparison to the amount of it within the leaves $(0.56 \pm 0.05)$. However, based on the result obtained, the amount of crude fiber content of our study was lesser, compared to the amount of the ones within the crude fiber content of Balanites aegyptica (Rampal et al.,
2010) and Ocimum grastismium (Idris et al., 2011). In fact, fiber content is highly essential for body. To illustrate this, the intake of fiber can lead to the decrease of serum cholesterol level for the requirement for insulin, hypertension, diabetes, breast cancer, and constipation (Ramulu and Rao, 2003). However, compared to leaves and flowers, O. tenuiflorum L. could be a valuable source of dietary fiber than leaf and flowers. There is a higher amount of value shown by the moisture content of O. tenuiflorum L., in comparison to the amount of value within the stems. Based on this result, it has been indicated that this plant is capable of a long term storage without getting spoiled (Bouba, 2012). Furthermore, the amount of moisture within the content of leaves and stems of $O$. tenuiflorum $\mathrm{L}$. was higher, in comparison to the amount of moisture from the whole plant of $O$. grastismum that reported by (Idris et al., 2011).

Moreover, the ash content of $O$. tenuiflorum $\mathrm{L}$. leaves almost doubled when compared with stems. However, the amount of ash in the leaves of $O$. tenuiflorum L. leaves was $0.3 \pm 0.05$, which displayed a significant difference from the stems $(0.17 \pm 0.06)$ at $\mathrm{p}<0.05$. The previous study of $O$. grastismium reported the result of the ash content that the amount within the stems and leaves were higher (Idris et al., 2011). Ash is an inorganic compound left after the removal of water and all organic and inorganic matter, which is performed by heating in the presence of oxidizing agents, which provides the overall amount of minerals within food (Bouba, 2012).

\subsection{Fatty acid profile of O. tenuiflorum L. leaves and stems}

The results of fatty acid analysis of the stem and leaves of $O$. tenuiflorum $\mathrm{L}$ are displayed in Table 2 . Based on the results, the butanoic acid showed the highest amount of fatty acid in stems and leaves, in comparison to other fatty acid compositions. However, the amount of saturated fatty acid in comparison to stems is slightly higher than the ones in the leaves. At this point, the results of saturated fatty acid profile in the leaves display the amount of methyl tetradecanoate in the stem. On the other hand, there was no significant difference shown by octadecanoic acid, tetracosanoic acid, docosanoic acid, eicosanoic acid, pentadeconoic acid, capronic acid, and octanoic acid. Out of all substances, the discovery of tricosanoic acid only occurred on leaves. Based on the previous study, the daily diet of capric acid $(>300 \mu \mathrm{M})$ is highly effective for the regulation of the secretion of insulin from pancreas $\beta$ -cell (Nagasumi et al., 2009). Besides, the presence of deanoic acid results to its usefulness in ester manufacturing to produce artificial fruit flavour and perfume (Anderson, 2008). 
Table 2. Fatty acid profile of Ocimum tenuiflorum L. leaves and stems

\begin{tabular}{|c|c|c|c|}
\hline Compound name & Chemical Compound & Leaves & Stems \\
\hline \multicolumn{4}{|l|}{ Saturated } \\
\hline Butanoic acid ME & $\mathrm{C} 4: 0$ & $66.87 \pm 2.31$ & $81.98 \pm 2.20 *$ \\
\hline Capronic acid & C6:0 & $0.94 \pm 0.58 *$ & $0.57 \pm 0.30$ \\
\hline Octanoic acid ME & $\mathrm{C} 8: 0$ & $2.49 \pm 0.4^{*}$ & $1.84 \pm 0.10$ \\
\hline Decanoic acid ME & $\mathrm{C} 10: 0$ & $0.15 \pm 0.02 *$ & $0.11 \pm 0.01$ \\
\hline Undecanoic acid ME & $\mathrm{C} 11: 0$ & $0.09 \pm 0.01 *$ & $0.03 \pm 0.05$ \\
\hline Dodecanoic acid ME & $\mathrm{C} 12: 0$ & $0.09 \pm 0.01 *$ & - \\
\hline Tridecanoic acid ME & $\mathrm{C} 13: 0$ & $0.55 \pm 0.05 *$ & $0.10 \pm 0.01$ \\
\hline Methyl tetradecanoate ME & $\mathrm{C} 14: 0$ & $0.06 \pm 0.04$ & $0.57 \pm 0.06^{*}$ \\
\hline Pentadecanoic acid ME & $\mathrm{C} 15: 0$ & $0.10 \pm 0.01$ & $0.01 \pm 0.00$ \\
\hline Hexadecanoic acid ME & $\mathrm{C} 16: 0$ & $1.70 \pm 0.23 *$ & $0.93 \pm 0.72$ \\
\hline Heptadecanoic acid ME & $\mathrm{C} 17: 0$ & $0.04 \pm 0.01 *$ & $0.02 \pm 0.01$ \\
\hline Octadecanoic acid ME & C18:0 & $0.12 \pm 0.02$ & $0.12 \pm 0.01$ \\
\hline Eicosanoic acid ME & C20:0 & $0.1 \pm 0.02$ & $0.07 \pm 0.01$ \\
\hline Heneicosanoic acid ME & $\mathrm{C} 21: 0$ & $0.03 \pm 0.01$ & $0.04 \pm 0.01$ \\
\hline Docosanoic acid ME & $\mathrm{C} 22: 0$ & $0.14 \pm 0.01$ & - \\
\hline Tricosanoic acid ME & $\mathrm{C} 23: 0$ & $0.29 \pm 0.05$ & $0.05 \pm 0.01$ \\
\hline Tetracosanoic acid ME & $\mathrm{C} 24: 0$ & $0.1 \pm 0.02$ & $0.07 \pm 0.01$ \\
\hline \multicolumn{4}{|l|}{ Unsaturated } \\
\hline Methyl myristoleate ME & $\mathrm{C} 14: 1$ & $0.10 \pm 0.02$ & $0.02 \pm 0.01$ \\
\hline 9-Hexadecenoic acid ME & C16:1 & $0.03 \pm 0.03$ & $0.02 \pm 0.01$ \\
\hline \multicolumn{4}{|l|}{ Polyunsaturated } \\
\hline Vaccenic acid & C $18: 1 n-7$ & $0.38 \pm 0.07$ & $0.34 \pm 0.04$ \\
\hline Oleic acid & C $18: 1 n-9$ & $0.34 \pm 0.05$ & $0.22 \pm 0.01$ \\
\hline$\gamma$ Linolenic acid ME & C $18: 3 n-6$ & $0.12 \pm 0.02$ & - \\
\hline $9,12,15$-Octadecatrienoic acid & C $18: 3 n-3$ & $3.47 \pm 0.50 *$ & $0.80 \pm 0.05$ \\
\hline 7,10,13-Eicosatrienoic acid & $C 20: 3 n-6$ & $0.07 \pm 0.02 *$ & $0.02 \pm 0.01$ \\
\hline Arachidonate acid ME & C $20: 4 n-6$ & $0.15 \pm 0.07$ & $0.04 \pm 0.01$ \\
\hline Methyl11,14,1 eicosatrienoate & $C 20: 3 n-3$ & $0.04 \pm 0.01$ & - \\
\hline Gondoic acid & C20:1n-9 & - & $0.04 \pm 0.01$ \\
\hline Docosapentaenoic acid n3 & $C 22: 5 n-3$ & $0.07 \pm 0.02 *$ & $0.02 \pm 0.01$ \\
\hline Dihomo-gamma-linolenic & $C 20: 3 n-6$ & $0.45 \pm 0.02$ & $0.11 \pm 0.01$ \\
\hline Docosahexaenoic acid & C22:6n-3 & $0.38 \pm 0.07$ & $0.34 \pm 0.04$ \\
\hline
\end{tabular}

Values are expressed as mean \pm SEM. *Significantly different $\mathrm{p}<0.05$.

Based on the result, there was no significant effect shown between the leaves and stems for the unsaturated fatty acid. The amount of polyunsaturated fatty acids compositions in the leaves was higher compared to the polyunsaturated fatty acids compositions in the stem. However, there was no significant effect shown by vaccenic acid, oleic acid, arachidonate acid, and docosahexaenoic acid. Based on the previous study, not only the long-term effects on glucose metabolism were displayed by eicosanoic and docosahexaenoic acids, they were also required as a precursor in the production of bio -diesel fuel (Anderson, 2008). In fact, oleic acid is a fatty acid which naturally exists within many kinds of animals, oils, and vegetable. This monounsaturated fat, besides having a relation with the decrease in lowdensity lipoprotein (LDL) cholesterol, it leads to the increase of high-density lipoprotein (HDL) cholesterol (Lunn et al., 2000). Moreover, due to the positive effects provided by lipoproteins metabolism, linolenic acid was recommended for the regulation of diabetes and heart disease (Oguanobi et al., 2012). Besides, linolenic acid is the most essential unsaturated omega- 6 fatty acid. Not only that, it is also a polyunsaturated fatty acid used for some prostaglandins and the biosynthesis of arachidonic acid (AA) (Nelson and Cox, 2005).

\subsection{Amino acid profile of $O$. tenuiflorum $L$. leaves and stems}

The essential and non-essential amino acid profile is displayed in Table 3. The level of hydroxyprolin within stems is higher compared to the leaves. However, there is a higher level of essential amino acid within leaves, in comparison to the ones within the stem. They consist of the amino acids within $O$. tenuiflorum leaves and stem (tryptophan and phenylalanine, leucine, isoleucine, methionine, valine, threonine, arginine, histidine, and lysine), and the daily intake for most of them is according to (Food and Agriculture Organization and 
World Health Organization, 2004) the reference values. Furthermore, these amino acids function as the untreated materials so that many other cellular products will be synthesized such as pigments, enzymes, and hormones.

In addition, a number of these amino acids are important for cellular metabolism (Krishna, 2013). Based on the result of non-essential amino acid profile, the number of amino acids within the leaves is the highest compared to those within the stem. Besides, the presence of cysteine can only be observed from leaves. Based on previous studies, cysteine has a role in protecting the beta cells of pancreas from oxidative stress (Yanpallewar et al., 2004). Additionally, previous studies have also found that arginine functions as anti-inflammatory for the proliferation of fibroblast cells among people who are diagnosed with diabetic wound healing (Algariri et al., 2013). According to the most recent report, insulin synthesis and sensitivity can be enhanced through the daily intake of glutamine (Krishna, 2013).

Table 3. Amino acid profile of Ocimum tenuiflorum L. leaves and stems

\begin{tabular}{lcc}
\hline \multirow{2}{*}{ Compound name } & \multicolumn{2}{c}{ Essential amino acid } \\
\cline { 2 - 3 } & \multicolumn{1}{c}{ Leaves } & Stems \\
\hline Hydroxyprolin & $0.56 \pm 0.08$ & $1.44 \pm 0.04^{*}$ \\
Histidine & $2.13 \pm 0.06^{*}$ & $1.73 \pm 0.05$ \\
Isoleucine & $4.15 \pm 0.03^{*}$ & $3.71 \pm 0.01$ \\
Leucine & $7.1 \pm 0.02^{*}$ & $6.40 \pm 0.07$ \\
Lysine & $5.85 \pm 0.12^{*}$ & $5.32 \pm 0.12$ \\
Methionine & $0.90 \pm 0.50^{*}$ & $0.63 \pm 0.01$ \\
Phenylalanine & $5.08 \pm 0.08^{*}$ & $3.93 \pm 0.03$ \\
Threonine & $4.43 \pm 0.06^{*}$ & $3.75 \pm 0.02$ \\
Tryptophan & $3.77 \pm 0.10^{*}$ & $2.86 \pm 0.02$ \\
Valine & $5.36 \pm 0.04^{*}$ & $4.84 \pm 0.03$ \\
Non-Essential amino acid & & \\
Alanine & $5.45 \pm 0.17^{*}$ & $4.78 \pm 0.06$ \\
Arginine & $5.08 \pm 0.23^{*}$ & $4.13 \pm 0.10$ \\
Aspartic acid & $11.20 \pm 0.10^{*}$ & $9.82 \pm 0.63$ \\
Cysteine & $0.05 \pm 0.00^{*}$ & - \\
Glutamine & $12.10 \pm 0.20^{*}$ & $12.70 \pm 0.60$ \\
Glycine & $4.10 \pm 0.12$ & $4.43 \pm 0.60$ \\
Proline & $5.26 \pm 0.06^{*}$ & $4.75 \pm 0.03$ \\
Serine & $4.71 \pm 0.20$ & $4.51 \pm 0.20$ \\
$\alpha$-Aminobutyric acid & $10.61 \pm 0.4$ & $21.12 \pm 0.06^{*}$ \\
Ammonia & $0.30 \pm 0.02$ & $0.40 \pm 0.01 *$ \\
\hline
\end{tabular}

Values are expressed as mean \pm SEM. *Significantly different $\mathrm{p}<0.05$.

\subsection{Vitamin compositions of O. tenuiflorum L. leaves and stems}

Based on the result of vitamin content presented in Table 4, there was a high content of water-soluble vitamins and fat-soluble vitamins in the leaves of $O$. tenuiflorum contain, compared to those in the stems. Due to the previous research, the presence of vitamins showed that the high benefits in management of diabetic mellitus. Regarding to previous report, Jäpelt et al. (2013) indicated that the vitamins E, B3, B12, and C, which are all free radical scavengers. As mentioned in previous reports, vitamin E showed the important role in protecting of the beta-cells of pancreas from oxidative stress (Wang et al., 2012). Furthermore, it has been reported that vitamin $\mathrm{C}$ gives impact to the post-meal glucose level in type II diabetes (Dakhale et al., 2011). Meanwhile, based on the recent report, the preserving beta-cells function can be enhanced by vitamin group B (B3, B12) which was effect on production of the insulin level in body (Patel et al., 2012).

Table 4. Vitamin compositions of Ocimum tenuiflorum L. leaves and stems

\begin{tabular}{lcc}
\hline \multirow{2}{*}{ Vitamins } & \multicolumn{2}{c}{ Amount $\mathrm{mg} / 100 \mathrm{~g}$} \\
\cline { 2 - 3 } & Leaves & Stems \\
\hline Vitamin E & $1.07 \pm 0.04^{*}$ & $0.22 \pm 0.063$ \\
Vitamin B3 & $0.078 \pm 0.02^{*}$ & $0.054 \pm 0.02$ \\
Vitamin B12 & $0.043 \pm 0.05^{*}$ & $0.027 \pm 0.02$ \\
Vitamin C & $0.0017 \pm 0.0006^{*}$ & $0.0010 \pm 0.000$ \\
\hline
\end{tabular}

Values are expressed as mean \pm SEM. *Significantly different $\mathrm{p}<0.05$.

3.5 Phytic acid, saponin of O. tenuiflorum L. leaves and stems.

Table 5 shows that the amount of phytic acid and saponin content of $O$. tenuiflorum L. leaves and stems. The phytic acid did not show any significant difference between the leaves and stems. Due to previous study reported that the percentage of phytic acid's proportion in dry matter of oilseeds, legume, and cereal, ranged from $10 \%$ to $30 \% \mathrm{~g} / \mathrm{kg}$. However, based on the previous research, the lowering of phytate should be done as much as possible. The acceptable amount of phytic acid in food contain was reported at $25 \mathrm{mg}$ or less per $100 \mathrm{~g}$ of the containing food in order to obtain the best physical condition (Inuwa et al., 2011). Moreover, there is a negative effect coming along with the excessive consumption of phytic acid in diet on mineral balance, due to the formation of insoluble complexes with essential mineral $\left(\mathrm{Cu}^{2+}, \mathrm{Zn}^{2+}, \mathrm{Fe}^{3+}\right.$ and $\left.\mathrm{Ca}^{2+}\right)$ and the reduction of the bioavailability of these minerals (Fordyce et al., 1987). In addition, it has also been shown that there is an interaction between phytate and the basic residues of proteins, which suppresses several digestive enzymes (Ekholm et al., 2003).

The result of saponin content in Table 5 indicated that the amount of saponin content within the leaves is slightly higher compared to the saponin content within the stems. Saponin is generally known as secondary 
compounds, which are acknowledged as surface active compounds and non-volatile (Manivannan et al., 2015). Furthermore, due to their positive effects of saponins on human's body, research about the effect of that is considerable interest (Edet et al., 2015) and the results of researcher indicated that consuming of saponins are necessary for healthy since saponins showed the effect on reducing the risk of heart disease by binding of that with plasma membrane and cholesterol (Ogunleye et al., 2016).

Table 5. Phytic acid, Saponin of Ocimum tenuiflorum L. leaves and stems

\begin{tabular}{ccc}
\hline Constituent & Leaves $(\mu \mathrm{g} / \mathrm{mL})$ & Stems $(\mu \mathrm{g} / \mathrm{mL})$ \\
\hline Phytic acid & $1.22 \pm 0.2$ & $0.99 \pm 0.15$ \\
Saponin & $0.23 \pm 0.03^{*}$ & $0.20 \pm 0.01$ \\
\hline
\end{tabular}

Values are expressed as mean \pm SEM. *Significantly different $\mathrm{p}<0.05$.

3.6 Phytochemical values of O. tenuiflorum L. leaves and stems

These non-nutrient plant chemical compounds or bioactive components are mostly known as phytoconstituents (phyto is Greek work which means plant) or phytochemicals. Their role is to protect plants against infestations by pests or microbial infections (Doughari, 2009). There has been separation and isolation occurring of phytochemicals from fruits, green tea, red wine, spices such as turmeric and vegetables like broccoli and onion, grapes and apples, and many other sources (Tiwari et al., 2011).

Table 6. Phytochemical constituents on dry weight basis expressed as $\mathrm{mg} / 100 \mathrm{~g}$

\begin{tabular}{lcc}
\hline Constituent & Leaves $(\mathrm{mg} / 100 \mathrm{~g})$ & Stems $(\mathrm{mg} / 100 \mathrm{~g})$ \\
\hline Phenols & $1.7 \pm 0.02^{*}$ & $0.77 \pm 0.03$ \\
Alkaloids & $2.9 \pm 0.40^{*}$ & $1.80 \pm 0.30$ \\
Tannins & $0.51 \pm 0.10^{*}$ & $0.16 \pm 0.02$ \\
Flavonoids & $1.16 \pm 0.20^{*}$ & $0.51 \pm 0.10$ \\
\hline
\end{tabular}

Values are expressed as mean \pm SEM. *Significantly different $\mathrm{p}<0.05$.

The overall content of phenols, alkaloids, tannins, and flavonoids within $O$. tenuiflorum $\mathrm{L}$. leaves and stems are displayed in Table 6 . In comparison to the phytochemical in the stems, the amount of phytochemical in leaves is higher. Based on the result, the duplication of the phenol content in leaves $(1.7 \pm 0.02)$ occurs more frequently compared to the stems $(0.77 \pm 0.03)$ of $O$. tenuiflorum L. Nevertheless, compared to the stems, the amount of alkaloid, flavonoid, and tannin contents within leaves were almost in duplicate and triplicate. Based on the previous study, the toxicity of alkaloids can occur from their high concentration, especially when it exceeds the lethal dose of $20 \mathrm{mg} / 100$ g (Inuwa et al., 2011). On the other hand, compared to other active compounds, the low toxicity of flavonoids provides humans with alternatives in their diet (Brill et al., 2012). According to the in vitro study that was reported by Adebajo et al., 2009, anti-allergic, antiinflammatory, and anti-diarrheal activity could be discovered within flavonoids. Furthermore, there are chemical components which are usually in the form of natural colour pigments. These components like polyphenolics, phenols, or phenolics (or polyphenol extracts) play a role in the colour of fruits (Shahidi and Naczk, 2006). The phenolic compounds mainly function in protect human body from herbivore predators and pathogens; they are utilized to manage pathogenic infections in human's body (Eghdami and Sadeghi, 2010). Meanwhile, the largest group of secondary chemical constituents are alkaloids, which mostly comprise of ammonia compounds (Tiwari et al., 2011). Aside from the function of the nitrogenous compounds of alkaloids as the protector of plants against pathogens and herbivores, they are widely used as poisons, narcotics, stimulants, and pharmaceuticals as they have strong biological activities (Moreno et al., 2006). Moreover, there is a wide distribution of tannin occurring among flora. They are the phenolic compounds of high molecular weight which can be discovered in the outer layers, stem, bark, and the root of plant tissue (Pawar, 2011). Flavonoids belong to an important group of polyphenols, which population is dominant amongst flora. Furthermore, there is more than one benzene ring in the structure of flavonoids (a range of $\mathrm{C} 15$ aromatic compounds). Apart from that, their use as antioxidants or free radical scavengers receives numerous supports from study reports (Doughari, 2009).

\section{Conclusion}

The potentials of $O$. tenuiflorum L. leaves as the abundant source of the important nutrients needed in daily diet were demonstrated in the results of this study. Besides, they have the potential as a useful supplement needed for managing degenerative diseases which are resulted from the generation of free radicals. Finally, based on previous studies, the level of antinutritional compounds in the leaves and stems of $O$. tenuiflorum $\mathrm{L}$. was found to be within the safe level. Besides, provided that these medicinal plants are a source of useful drugs, it is important to consume them in moderate amount for the improvement of health conditions.

\section{Conflict of Interest}

The authors declare no conflict of interest. 


\section{Acknowledgments}

This work was funded by a grant of Universiti Sains Malaysia RU grants (1001/PTEKIND/6711526) contributed to the funding of this research. The financial support for post-doctoral fellowship scheme from Universiti Sains Malaysia for co-author Leila Mousavi was gratefully acknowledged.

\section{References}

Adebajo, A. C., Iwalewa, E.O., Obuotor, E.M., Ibikunle, G.F., Omisore, N.O., Adewunmi, C.O., Obaparusi, O.O., Klaes, M., Adetogun, G.E., Schmidt, T.J. and Verspohl, E.J. (2009). Pharmacological properties of the extract and some isolated compounds of Clausena lansium stem bark: Anti-trichomonal, antidiabetic, anti-inflammatory, hepatoprotective and antioxidant effects. Journal of Ethnopharmacology, 122, $\quad 10-19 . \quad$ https://doi.org/10.1016/ j.jep.2008.11.015

Algariri, K., Meng, K.Y., Atangwho, I.J., Asmawi, M.Z., Sadikun, A., Murugaiyah, V. and Ismail, N. (2013). Hypoglycemic and anti-hyperglycemic study of Gynura procumbens leaf extracts. Asian Pacific Journal of Tropical Biomedicine, 3(5), 358-366. https://doi.org/10.1016/S2221-1691(13)60077-5

Anderson, D.C. (2008). Assessment and Nutraceutical Management of Stress-induced Adrenal Dysfunction. Integrative Medicine, 7, 18-25.

Association of Official Analytical Chemists (AOAC). (2000). Official methods of analysis of AOAC International. $17^{\text {th }}$ ed. Gaithersburg, MD, USA: AOAC.

Baccou, J.C., Lambert, F. and Sauvaire, Y. (1977). Spectrophotometric method for the determination of total steroidal sapogenin. Analyst, 102, 458-465. https://doi.org/10.1039/an9770200458

Bidlack, W.R., Omaye, S.T., Meskin, M.S. and Topham, D.K.W. (2000). Phytochemicals as bioactive agents. USA: CRC press. https:// doi.org/10.1201/9781482278880

Boham, B.A. and Kocipai-Abyazan, R. (1974). Flavonoids and condensed tannins from leaves of Hawaiian vaccinium vaticulatum and V. calycinium. Pacific Science, 48, 458-463.

Bouba, A.A. (2012). Proximate Composition, Mineral and Vitamin Content of Some Wild Plants Used as Spices in Cameroon. Food and Nutrition Sciences, 3, 423-432. https://doi.org/10.4236/fns.2012.34061

Brill, S., Falk, O.S. and Schuldiner, S. (2012). Transforming a drug/H+ antiporter into a polyamine importer by a single mutation. Proceedings of the
National Academy of Sciences, 109, 16894-16899. https://doi.org/10.1073/pnas.1211831109

Dakhale, G.N., Chaudhari, H.V. and Shrivastava, M. (2011). Supplementation of vitamin C reduces blood glucose and improves glycosylated hemoglobin in type 2 diabetes mellitus: a randomized, double-blind study. Advances in Pharmacological Sciences, 2011, 1-5. https://doi.org/10.1155/2011/195271

Doss, A. (2009). Preliminary phytochemical screening of some Indian medicinal plants. Ancient Science of Life, 29(2), 12-16.

Doughari, J.H. (2009). Phytochemicals: Extraction Methods, Basic Structures and Mode of Action as Potential Chemotherapeutic Agents, p. 1-33.. Retrieved from Intech open website: https:// www.intechopen.com/books/phytochemicals-aglobal-perspective-of-their-role-in-nutrition-andhealth/phytochemicals-extraction-methods-basicstructures-and-mode-of-action-as-potentialchemotherapeutic-

Edeoga, H.O., Okwu, D.E. and Mbaebie, B.O. (2005). Phytochemical constituents of some Nigerian medicinal plants. African Journal of Biotechnology, 4, 685-688. https://doi.org/10.5897/AJB2005.0003127

Edet, A., Eseyin, O. and Aniebiet, E. (2015). Antinutrients composition and mineral analysis of allium cepa (onion) bulbs. African Journal of Pharmacy and Pharmacology, 9, 456-459. https:// doi.org/10.5897/AJPP2015.4300

Eghdami, A. and Sadeghi, F. (2010). Determination of Total Phenolic and Flavonoids Contents in Methanolic and Aqueous Extract of Achillea Millefolium. Organic Chemistry Journal, 2, 81-84.

Ekholm, P., Virkki, L., Ylinen, M. and Johansson, L. (2003). The effect of phytic acid and some natural chelating agents on the solubility of mineral elements in oat bran. Food Chemistry, 80(2), 165170. https://doi.org/10.1016/S0308-8146(02)00249-2

Eknayake, S., Jansz, E.R. and Nair, B.M. (1999). Proximate composition, mineral and amino acid content of mature Canavalia gladiata seeds. Food Chemistry, 66(1), 115-119. https://doi.org/10.1016/ S0308-8146(99)00041-2

Food and Agriculture Organization and World Health Organization. (2004). Vitamin and mineral requirements in human nutrition. 2nd ed. Rome: FAO

Farhat, C., Lesoinne, M., LeTallec, P., Pierson, K. and Rixen, D. (2001). FETI-DP: a dual-primal unified FETI method-part I: A faster alternative to the twolevel FETI method. International Journal for 
Numerical Methods in Engineering, 50(7), 15231544. https://doi.org/10.1002/nme.76

Fordyce, E.J., forbes, R.M., Robbins, K.R. and Erdman, J.W. (1987). Phytate $\times$ calcium/zinc molar ratios: are they predictive of zinc bioavailability? Journal of Food Science, 52(2), 440-444. https:// doi.org/10.1111/j.1365-2621.1987.tb06634.x

Idris, S., Iyaka, Y.A, Ndamitso, M.M. and Paiko, Y.B. (2011). Nutritional Composition of the Leaves and Stems of Ocimum gratissimum. Journal of Emerging Trends in Engineering and Applied Sciences, 2(5), 801-805.

Inuwa, I.M., Taranikanti, V., Al-Rawahy, M. and Habbal, O. (2011). Perceptions and attitudes of medical students towards two methods of assessing practical anatomy knowledge. Sultan Qaboos University Medical Journal, 11, 383.

Jäpelt, R.B., Silvestro, D., Smedsgaard, J., Jensen, P.E. and Jakobsen, J. (2013). Quantification of vitamin D3 and its hydroxylated metabolites in waxy leaf nightshade (Solanum glaucophyllum Desf.), tomato (Solanum lycopersicum L.) and bell pepper (Capsicum annuum L.). Food Chemistry, 138(2-3), 1206-1211.

j.foodchem.2012.11.064

Kokke, R. (1977). Improvement of Carob Pods as Feed by Solid-substrate Fermentation. Journal of Applied Microbiology, 43(2), 303-307. https:// doi.org/10.1111/j.1365-2672.1977.tb00755.x

Kothari, S.K., Bhattacharya, A.K. and Ramesh, S. (2004). Essential oil yield and quality of methyl eugenol rich Ocimum tenuiflorum L.f. (syn. O. sanctum L.) grown in south India as influenced by method of harvest. Journal of Chromatography A, 1054(1-2), 67-72. https://doi.org/10.1016/ j.chroma.2004.03.019

Krishna, M. (2013). Microscopic anatomy of the liver. Clinical Liver Disease, 2(S1), S4-S7. https:// doi.org/10.1002/cld.147

Lintas, C. and Cappelloni, M. (1992). Dietary fiber content of Italian fruit and nuts. Journal of Food Composition and Analysis, 5(2), 146-151. https:// doi.org/10.1016/0889-1575(92)90030-N

Lunn, D.J., Thomas, A., Best, N. and Spiegelhalter, D. (2000). WinBUGS-a Bayesian modelling framework: concepts, structure, and extensibility. Statistics and Computing, 10(4), 325-337. https:// doi.org/10.1023/A:1008929526011

Magness, V. (2006). Strategic posture, financial performance and environmental disclosure: an empirical test of legitimacy theory. Accounting, Auditing and Accountability Journal, 19(4), 540-
563. https://doi.org/10.1108/09513570610679128

Manivannan, J., Shanthakumar, J., Silambarasan, T., Balamurugan, E. and Raja, B. (2015). Diosgenin, a steroidal saponin, prevents hypertension, cardiac remodeling and oxidative stress in adenine induced chronic renal failure rats. RSC Advances, 5(25), 19337-19344. https://doi.org/10.1039/C4RA13188F

Moreno, D. A., Carvajal, M., López-Berenguer, C. and García-Viguera, C. (2006). Chemical and biological characterisation of nutraceutical compounds of broccoli. Journal of Pharmaceutical and Biomedical Analysis, 41(5), 1508-1522. https://doi.org/10.1016/ j.jpba.2006.04.003

Mousavi, L., Salleh, R.M. and Murugaiyah, V. (2014). Comparison of Antimicrobial Activity of Different Extract of Ocimum tenuiflorum L . leaf and Stem. Annual Research and Review in Biology, 4(24), 3742-3750.

https://doi.org/10.9734/ ARRB/2014/11058

Mousavi, L., Rabeta, M.S., Vikneswaran, M. and Mohd Zaini, A. (2016). Hypoglycemic and antihyperglycemic study of Ocimum tenuiflorum L. leaves extract in normal and streptozotocin-induced diabetic rats. Asian Pacific Journal of Tropical Biomedicine, 6(12), 1029-1036. https:// doi.org/10.1016/j.apjtb.2016.10.002

Nagasumi, K., Esaki, R., Iwachidow, K., Yasuhara, Y., Ogi, K., Tanaka, H., Nakata, M., Yano, T., Shimakawa, K. and Taketomi, S. (2009). Overexpression of GPR40 in pancreatic $\beta$-cells augments glucose-stimulated insulin secretion and improves glucose tolerance in normal and diabetic mice. Diabetes, 58(5), 1067-1076. https:// doi.org/10.2337/db08-1233

Nelson, D.L. and Cox, M.M. (2005). Lehninger principles of biochemistry. London: Macmillan Publishers

Oguanobi, N.I., Chijioke, C.P. and Ghasi, S. (2012). Neonatal Streptozotocin-Induced Type-2 Model Diabetic Rats. International Journal of Pharmaceutical Science, 4(5), 77-83.

Ogunleye, A.G., Oyeniran, K.A., Adedeji, O.A. and Boboye, B. (2016). Phytochemical compositions and antibacterial effects of crude extract of leaf of Moringa oleifera on bacteria iso-lates from well water at Iworoko-Ekiti, Nigeria. Annals of Complementary and Alternative Medicine, 1, 11-17.

Patel, D.K., Prasad, S.K., Kumar, R. and Hemalatha, S. (2012). An overview on antidiabetic medicinal plants having insulin mimetic property. Asian Pacific Journal of Tropical Biomedicine, 2(4), 320-330. https://doi.org/10.1016/S2221-1691(12)60032-X 
Pawar, C.D., Patil, A.A. and Joshi, G.D. (2011). Physico -chemical parameters of sapota fruits at different maturity stages. Journal of Farm Sciences, 24, 420421.

Rabeta, M.S. and Lai, S.Y. (2013). Effects of drying, fermented and unfermented tea of ocimum tenuiflorum linn. on the antioxidant capacity. International Food Research Journal, 20, 16011608

Rai, V., Vajpayee, P., Singh, S.N. and Mehrotra, S. (2004). Effect of chromium accumulation on photosynthetic pigments, oxidative stress defense system, nitrate reduction, proline level and eugenol content of Ocimum tenuiflorum L. Plant Science, 167(5), 1159-1169. https://doi.org/10.1016/ j.plantsci.2004.06.016

Rampal, S., Rampal, L., Rahmat, R., Zain, A.M., Yap, Y.G., Mohamed, M. and Taha, M. (2010). Variation in the prevalence, awareness, and control of diabetes in a multiethnic population: a nationwide population study in Malaysia. Asia-Pacific Journal of Public Health / Asia-Pacific Academic Consortium for Public Health, 22(2), 194-202. https:// doi.org/10.1177/1010539509334816

Ramulu, P. and Rao, P.U. (2003). Total, insoluble and soluble dietary fiber contents of Indian fruits. Journal of Food Composition and Analysis, 16(6), 677-685. https://doi.org/10.1016/S0889-1575(03) 00095-4

Ratti, C. (2001). Hot air and freeze-drying of high-value foods: A review. Journal of Food Engineering, 49 (4), 311-319. https://doi.org/10.1016/S0260-8774 (00)00228-4

Rohini, J., Mansoureh, N.V., Fouad Saleih, R.Al-S., Rabeta, M.S. and Amin Malik Shah, A.M. (2019). Preliminary screening on wound healing potential of Ocimum tenuiflorum L. using in vitro assays. Food Research, 3(3), 58 - 264. https://doi.org/10.26656/ fr.2017.3(3).010

Santos, J., Mendiola, J.A., Oliveira, M.B.P.P., Ibáñez, E. and Herrero, M. (2012). Sequential determination of fat- and water-soluble vitamins in greenleafy vegetables during storage. Journal of Chromatography A, 1261, 179-188. https:// doi.org/10.1016/j.chroma.2012.04.067

Shahidi, F. and Naczk, M. (2006). Phenolics in food and nutraceuticals. New York: CRC Press.

Strydom, D.J. and Cohen, S.A. (1994). Comparison of amino acid analyses by phenylisothiocyanate and 6aminoquinolyl-N-hydroxysuccinimidyl carbamate precolumn derivatization. Analytical Biochemistry, 222(1), 19-28. https://doi.org/10.1006/ abio. 1994.1448

Tayade, A.B., Dhar, P., Kumar, J., Sharma, M., Chaurasia, O.P. and Srivastava, R.B. (2013). Sequential determination of fat-and water-soluble vitamins in Rhodiola imbricata root from transHimalaya with rapid resolution liquid chromatography/tandem mass spectrometry. Analytica Chimica Acta, 789, 65-73. https:// doi.org/10.1016/j.aca.2013.05.062

Tiwari, P., Kumar, B., Mandeep, K., Kaur, G. and Kaur, H. (2011). Phytochemical screening and Extraction: A Review. Internationale Pharmaceutica Sciencia, 1, 98-106.

Vaintraub, I.A. and Lapteva, N.A. (1988). Colorimetric determination of phytate in unpurified extracts of seeds and the products of their processing. Analytical Biochemistry, 175(1), 227-230. https:// doi.org/10.1016/0003-2697(88)90382-X

Wang, H., Liu, T., Song, L. and Huang, D. (2012). Profiles and $\alpha$-amylase inhibition activity of proanthocyanidins in unripe Manilkara zapota (Chiku). Journal of Agricultural and Food Chemistry, 60, 3098-3104. https://doi.org/10.1021/ jf204715q

Yanpallewar, S.U., Rai, S., Kumar, M. and Acharya, S.B. (2004). Evaluation of antioxidant and neuroprotective effect of Ocimum sanctum on transient cerebral ischemia and long-term cerebral hypoperfusion. Pharmacology Biochemistry and Behavior, 79(1), 155-164. https://doi.org/10.1016/ j.pbb.2004.07.008 